\title{
The Role of Mirriiysaa: Function in Focus
}

\author{
Sebsibe Getahun \\ Department of Afan Oromo and Literature, Dire Dawa University, Ethiopia
}

\begin{abstract}
The objective of this study is to analyze the role of Mirriiysaa (Mirriga) in socio-political context. To achieve this goal, an attempt was made in collecting poems of Mirriiysaa that depict the socio- political function. The two instruments of data collection were an open-ended interview and complete observation. All the collected data were translated into English and analyzed functionally. The study shows that Mirriiysaa is sung for different functions in Hararge Oromo. Because, these people use Mirriiysaa to express their social, political, economical and cultural issues, besides instructing each other about their political, economical and social life. The same clan does not sing Mirriiysaa to one another. Mostly this song is sung by elders. But sometimes also it is sung by women and youths. But youths do not sing with elders. Youths from the same clan cannot sing Mirriiysaa together. But from different clan they can sing together. Elders from the same clan also cannot sing with each other. But from different clan they also can sing together. Mirriiysaa is sung mostly at morning time. Sometimes it is sung at evening and at the afternoon. When playing this song, elder singers have in their hands a cultural material called 'Alangaa' (a whip). Hararge people reflect their social and political codes through their oral narratives which the Mirriiysaa (Mirriga) is amongst.
\end{abstract}

Keywords: Mirriiysaa, Mirriga, Hararge, Oromo, Socio-political, Function

DOI: $10.7176 / \mathrm{JCSD} / 48-01$

Publication date:May $31^{\text {st }} 2019$

\section{Introduction}

The study of folklore in our country seems to be of recent time development though attempts have been made to collect oral literature for quite long.

Ethiopian folklore research had been limited until the second half of the twentieth century.

The folkloric materials of the various ethnic groups in Ethiopia have not been studied very well and widely.

Through the folklore people can educate each other; perpetuate, challenge or modify a group's social norms and values; inform others about the basis for or nature of their culture; reveal or display their identity, traditionalist, knowledge, or competence; and entertain or be entertained. Georges and Jones (1995:170).

It seems that folklore has a potential contribution to political, social, cultural and economic realities and that has not been understood in context of roles/functions. "Songs can be used to report and comment on current affairs, for political pressure, for propaganda, and to reflect and mould public opinion" (Finnegan,1970).

In addition to this she stated, "In different contexts songs can have the effect of intensifying factional differences or of encouraging national unity" (Finnegan, 1970:270).

So, I believe that the range of complexity and role of research through the use of folklore have not been exhaustively researched particularly in Hararge Oromo. The Oromo belong to the original family of Cushitic peoples lived in the central highlands of the North-Eastern and Eastern Africa which is known as "Ethiopia" for thousands of years (Hussein 2006). The Oromo people as a whole is divided into two main branches. The Borana and the Barentu. But the Oromo clans which are found in Harerghe are the branch of Barentu (Karayu, Tumuga, Merawa, ItuHumbana and Qallo). These Hararge people occupied the north Eastern part of the Ethiopia and live in the present Eastern Oromia region. The researcher is interested in Hararge Oromo's social and historical as well as cultural background and feels it needs to be understood in order to understand the contextual uses of their oral literature. It is strongly related to the social realities and traditional practices of the society. Thus, familiarity with oral literature (especially with Mirriiysaa) of those people can help a reader to understand their social, political, economical, and cultural background.

\section{Description of the study area}

Hararghe as it was known to be one of political structures (Awraja) found in the previous regimes of the current Ethiopia, is now divided in to Western and Eastern Hararghe. Presently, according to the political structure of the country, Eastern Hararghe and Western Harerghe are the two of the 19 zones of Oromia regional state. The Harerege highlands cover an area of approximately 1500000 ha, stretching from Galamso and Chiro Mountain in the West to Kundudo Mountain in the East. Hararghe is located to the East of Addis Ababa, the capital city of Ethiopia, at about 400k.m and shares boundary with Djibouti and Hargesa to the West. The topography of the Harerge zones are full of trains (ups and downs) which ranges from low land to the highest pick in the district and the climate of an area range from low land (Gammoojjii) to high land (Baddaa). East Hararghe has 19 woredas (district equivalent) of which four are in the lowlands $(<1500 \mathrm{~m})$, and the remaining ones are located at 
higher altitudinal ranges $(>2000 \mathrm{~m})$ (Zonal office of Agriculture) West Hararghe is subdivided into 14 woredas the majority of which are lowland areas. Both zones have two rainy seasons, the short rainy season and the main rainy season, with a mean annual rainfall ranging from below $700 \mathrm{~mm}$ in the lowlands to nearly $1200 \mathrm{~mm}$ at higher altitudes. Most of the people living in Hararghe lowlands are nomadic agro-pastoralists who move their livestock seasonally, following grazing opportunities and water availability. Due to this favorable climatic condition, both cash crops and food crops are produced during different seasons of the year (Eastern Hararge Zonal office of agriculture).

\section{Objectives of the Study}

General Objective

The general objective of this study is to find out the major social and political role of Mirriiysaa in the society.

\section{Specific Objectives}

Based on the major objective mentioned above, this study intends to:

- Describe the theme of Mirriiysaa

- Describe the setting of Mirriiysaa

- Analyze the extent to which Mirriiysaa portray the socio-political realities of the Hararge Oromo society

\section{Instruments and Measurements}

The study used, in depth open-ended interview and complete observation instruments for data collection.

\section{Sampling Techniques and Procedures}

The research is of a qualitative type. For a qualitative research, there are different types of sampling techniques. For this particular study, the non-probability sampling design was employed. Considering the two zones (East and West Hararge) as the main stratum, the sample sites were determined through non probability sampling techniques. From the total 33 weredas found in both Hararge, I took two weredas that are Melka Bal'o wereda from East Hararge and Oda Bultum wereda from West Hararge. To determine the number of target population, the study used purposive (non probability) sampling. I also used purposive and snowball sampling to select elders.

\section{Observation}

A complete observation was held on actual group of elders sing Mirriiysaa (Mirriga).

\section{Interview}

An interview helps to address the elders who sing Mirriiysaa song, elders who are known to have a good about Mirriiysaa from each sample woreda's were considered for an open ended interview. I preferred using openended interview so that an interviewee says/responds/ a lot without any limitation. Therefore, three (3) elders from each wereda totally six (6) elders were selected.

\section{Data Analysis}

The data was analyzed using qualitative data analysis techniques.

\section{Scope of the Study}

This study mainly focused on the roles of Mirriiysaa. The study was limited to the Hararghe Oromo for the reason that Mirriiysaa is particularly the popular song of Hararghe people as well as the researcher is also very familiar with the target people and the area so that he can easily address the intended objectives of the study. So, the specific area of this reaserch is on two Weredas- Melka Bal'o from East Hararge and Oda Bultum from West Hararge.

\section{Results and Discussion}

Definition: Mirriiysaa is the cultural song which is sung especially by the elders (mostly above the age of about 35). As my informants told me though mostly Mirriiysaa is sung by the elders, it sometimes also sung by the youths who have shared experiences from the elders. They sit in an organized form and sing sitting in a form of circle. Also they sing standing on their foot with a little walking here and there. They all never sing together at the same time. From the group, one person sing and the other members of the group listen to him saying 'buli buli buli' to mean long live! Not only this, the members also use a single attractive word 'Hayyee' (to mean ok! you are right,...) immediately after the singer. The second singer continues as the first singer informs them his 
being tired. It continues by turn as such. In Mirriiysaa the poet starts in requesting the audiences so that they can listen to him/her effectively. He/she starts in saying 'Dhagahii dhaggeeffadhuu guurii gurraa fudhadhuu'. It means that 'Take out any wastage from your ear and listen to me'. The poet is telling the audiences how much important what is going to be said is. The issue is very important. Here, the audiences listen to the poet very attentively.

Not only when to start but also the poet ends the song in inviting the audiences so that they express their feeling. The poet ends by saying 'Akkanaan jechuu beeka waani naan jettuun eegaa'. This is to mean 'I said all what I know let me listen to your feedback'. Here, the poet gives a chance to the audiences as they can express any feeling. On the other hand, it is the way of giving a chance to the next Mirriiysaa singer. The next person can take a turn if there.

In singing Mirriiysaa we did not observe the prearranged and structured body movement performance. They move their body to the left and right in a slow motion. Singers never use any music materials except their words. But elder singers have in their hands a cultural material called 'Alangaa' (a whip). The same clan does not sing to one another. As said above, mostly this song is sung by elders. But sometimes also it is sung by women and youths. But youths do not sing with elders. Youths sing with the other clan youths. Elders from the same clan also do not sing with each other. Because in Mirriiysaa there might be words which one clan use to irritate the other clan. Here not to truly irritate each other but it is about just to scoff.

Not only this, in Mirriiysaa a singer appreciates the other clan. So, it is believed that one cannot exaggerate/appreciate himself rather he prefers to appreciate the others. There is a saying which says 'Abbaan of hin faarsu;dhagaan of hin darbu' to mean 'one cannot preach something good about himself and the stone cannot throw itself. So, let the others speak one's positive manner'. In general, Mirriiysaa is a song which the Hararge people use to express their different social cases, political cases (war song), cultural and economical cases.

The socio-political function of Mirriiysaa: The knowledge of a society implies some socio-political reality of the people and it helps to understand about society through oral literature (Marshal G, 1992: XiX). Therefore, this shows that different cultural songs emerged from society's socio-political life (Desta, 2015). Oral literature has a great role for the society. They reflect philosophy and values of a society that produces many societies; they are traditionally served many functions (Dorson, R.1972). Cultural songs of any society are related to their traditional practices and present time pointer (Finnegan, R (1970). According to the information gathered from the informants, the function of Mirriiysaa is to exhibit socio-political function. Then, the researcher has taken an example of 6 (six) poems of Mirriiysaa which serves as socio-political function in Hararge Oromo as follows:

1. Dhagahii dhaggeeffadhuu

Guurii gurraa fudhadhuu

Bakka gosti bule

Mirriiysaan beekanii

Bakka wadaajni bule

Shubbisaan beekanii

Bakka guuzni oole

Darashumaan beekanii

Akkanaan jechuu beeka

Waani naan jettuun eegaa

\section{Translation}

Let you get ready to listen to me

Where there is a clan is known by mirriiysaa

Where there is 'wadaajaa'(a huge group of people) is known by shubbisaa (cultural dance performance)

Where there are working men is known by darassii (cultural song of work)

I know saying so, and I am waiting for your feedback

\section{Analysis}

As I tried to understand from my respondents, in the above poem, there is a relationship between the Hararge Oromo and their different cultural songs. Where there is a clan there is also Mirriiysaa and Shubbisaa. The people work collectively (guuza) also sings the cultural song called darassii in order to inspire each other. It is about how people use oral literature when working together and being together for different matters in social cases. On the other hand, it is to mean that where there is clan, there would not be depression. Every body enjoys and get happy. Because, there are mirriiysaa and shubbisaa there. That is true. Even I was very interested with them and their song made me happy when observation.

2. Gangalataa wadalaa

Daaraarraayiin dadhabee

Saree guddisaa badde

Gandarraayiin dadhabee 


\section{Gowwaan gaagura onaa \\ Marageetiin dadhabee}

\section{Translation}

The week donkey

I am tired of waiting it from the dust

The stupid dog

I am tired of telling it not to go here and there

The foolish empty vessel man

I am tired of painting/building him

\section{$\underline{\text { Analysis }}$}

Here, as my informants, the father is blaming and informing the misbehavior of his son to the group members he is singing with. The young male Donkey likes to play in the ash/dust. In the above poem, the figurative speech which is called allegory is used. That's 'wadalaa' the name of the male Donkey. Sometimes, in order to talk about the people we may talk about animals. That is an allegory. The singer is saying that he couldn't guide his wadalaa (donkey) for its being misbehaved. The donkey wants to play in ash/dust. Also he couldn't use his own dog for its being misbehaved. The dog also always goes in the village to search for the food though it eats much food at its home. Like this, he also couldn't guide his own son for his being foolish. So, the singer believes that guiding a foolish person is very tiresome. As in everywhere, in Hararge Oromo also fathers advise and guide their sons so that their sons would achieve an expected and desired goal. But if a father is tired of advising and guiding his own son, he tells to the group sing Mirriiysaa. They call his son and advise as effectively as possible and give him the warning as needed as necessary. If impossible here, they may also tell to the Damina (head of the clan). What can be understood from this is that one's son is also the son of the clan. So, everybody belongs to clan. This shows how much they love each other. As the information gained from the informants, this love also played a great role in their social development. On mourning, working, on different ceremonies they become together because of their love. In the above song, the foolish boy is said to be an empty vessel. So this is a metaphorical figurative speech.

3. Hadiisa Qaalluutu qabaa

Ilmii Shariifaatu qabaa

Gabaree Nooleetu qabaa

Alaatu arjummaa qabaa

Jaarsootu hayyummaa qabaa

Boonaafi jeeynummaa Oborraatu qabaa

Oromoo rabbiitu olqabee

Eenyuutu mataa gadqabaa!

\section{Translation}

Hadis belongs to Qallu

Ilmi belongs to Sharifa

Good working man is of Nole

He who gives what he has belongs to Ala

The wise belongs to Jarso

Good looking man and hero is of Obora

It is God who bless Oromo

Whom do you think glare at Oromo!

\section{Analysis}

Here, Qallu, Sharifa, Nole, Meta, Ala, Jarso and Obora are the ancestors of Barentu-the son of Oromo. The singer of Mirriiysaa in the above poem is appreciating the sons of Barentu. He is appreciating them as Qallu is good in the history of religion (Haddis), Sharifa is good in the knowledge of religion (Ilmi), Nole is a hard working, Ala is a one who shares what he has with his clan, Jarso is a wise and Obora is a good looking person. To summarize the central meaning of the above poem, it is to instruct that Hararge Oromo is good in many aspects.

4. Dhagahii dhaggeeffadhuu

Guurii gurraa fudhadhuu

Mukni qunnee gubatee

Daaraan waleenso ciisaa

Akka biishaan haroodhaa

Waatu garaa naciisaa

\section{Translation}

Let you get ready to listen to me

The trees in Qunnee (the name of the place) are burnt 
The dust lay in Walenso (the name of the place)

Like there is something in lake, there is also something in me.

\section{Analysis}

The above Mirriiysaa song has the political perspective. As the respondents, the trees in Qunnee are burnt is to say the Oromo people in Qunnee are in trouble. Symbolically, the noun 'trees' becomes similar with the people. As the trees grow up they serve the people. The poet above makes similar the trees with the people. In the Derg regime the dictatorial government attacked the Oromo people in Qunnee. These people migrated from Qunnee to Waleensoo- an area near Qunnee. Here in the above poem, the singer wants to tell the fact that the Oromo people were attacked by the government in all the past governments. The deep silent lake became similar with the singer's deep silent sorrow. The figurative speech in this poem is simile. Lake and deepen sorrow became similar.

5. Maanguddoo teenya fixanii

Aarrii waan gaara ciisaa

Dardara keenya fixanii

Filaa waan gaara ciisaa

Shamarran teenya fixanii

Callee waan gaara ciisaa

Haawwan keenya fixanii

Guftaa waan gaara ciisaa

Oromoo lammii tiyya

Dhiigaatu garaa na ciisaa

Yoomiin galee gacciisaa

\section{Translation}

They have all killed our elderly men; their 'aarrii' (grey hairs) lay in the forest

They have all killed our young men; their combs (cultural wooden combs) lay in the forest

They have all killed our young ladies; their ornamental beads lay in the forest

They have all killed our elderly women; their 'guftaa' (cultural material used to combine hairs) lay in the forest How can I go home and get sleep there is an immense of blood with a sense of revenge in me.

\section{Analysis}

The enemy killed all our elderly men and women in the forest, they also have killed our youngsters and they have killed all our elderly women (mothers). As age goes along, the hair of the elderly men becomes white. An elderly men's white hair is 'Aarrii'. It was this 'aarrii' that was found in the forest as the poet says. 'Filaa' is a cultural wooden comb which especially male youths use to comb their hairs. As the peom above, it is these combs which were found in the forest. That is the male youths whose these combs were killed. 'Callee' is a cultural material which young females put on their necks. The poet says the forest is full of 'Callee' whose killed young female's materials. Here, as I understood, it is to mean that every person under any age and sex was attacked and killed by the enemy. Only their materials were found in the forest. They all were already killed. As the informants, the singer is saying if all these my blood relatives have been killed by the cruel enemy, how can I go to bed to sleep? I never do it. Here, the singer is in a deep sorrow. He definitely intended to revenge the enemy. As it was said above, the Hararge Oromo use oral literature to attack the enemy. In oral literature they try to revenge the enemy as forcefully as possible. If the enemy continues attacking them, the Oromo take harsh attack on their enemy so that the enemy would never be seen again. That is why the Oromo wanted to revenge as we can understand from the above politics Mirriiysaa poem. The phrase 'Dhiigaatu garaa na ciisaa' is to mean my stomach is full of blood. The poet is expressing how much he/she is in a deep sorrow. The last line which says 'Yoomiin galee gacciisaa' is to mean without mental peace to go to the bed to sleep is difficult. In the above poem, symbolism figurative speech. That's 'aarrii' symbolically expresses elders. 'Filaa' expresses youths. 'Callee' expresses females and ' $g u f t a a$ ' expresses women.

6. Dhagahii dhaggeeffadhuu

Guurii gurraa fudhadhuu

Halkaniin deema malee

Waraabo kophee hin qabuu

Caccabseet nyaata malee

Leenci gaachana hin qabuu

Useeti deema malee

Kofleetiin taphadha malee

Diina waliin garaan fayyaa na'n qabuu

\section{Translation}

Let you get ready to listen to me

The hyena doesn't have shoes though it goes at night

The lion doesn't have gaachana (cultural war material called sheld) though it eats breaking everything 
I go unconsciously and play with people being unhappy

I don't have happy with enemy though I play with them.

Analysis

The above Mirriiysaa poem, tells us that though the singer plays with the people, he is not happy at himself because the enemy destroyed his heart that he couldn't be happy. In this poem, the singer (indirectly) seems as if he wants to attack the enemy whenever possible. A hyena doesn't have shoes but it goes at night. At the day time one can go without wearing shoes because he can see as it is light. But in the night one must wear shoes so that he can protect his legs from danger. If one completely cannot get shoes, he goes in the night because there is no alternative other than going barefoot. Similarly, a hyena doesn't have shoes but it goes at night to find for the food. The singer of the above mirriiysaa is saying that he is not happy with his enemy though he plays with them. There is no alternative other than talking and playing with his enemy because if he doesn't play with them they might attack him. In addition to this, the singer says 'the lion eats any powerful animal though it doesn't have gaachana' (cultural war material called shield). Here, the singer is saying that as a Lion kills any powerful animals without a shield I also have the potential of killing my enemies. In the above poem, the figurative speech called personification can be observed. A shoe is only for human being. But in the above poem it is wished for a hyena. The poet gave the hyena the behavior of human being. Similarly, a shield is not for a Lion rather for human being. Here also the Lion is given the behavior of human being.

\section{Conclusion and Recommendations Conclusion}

Mirriiysaa is a cultural song which the Hararge Oromo uses in different social and political cases. The originality of Mirriiysaa is the Hararge Oromo itself. Mirriiysaa, which is a record of the Hararge Oromo's experience, has continued to be the most instructive subject in that it helped the succeeding generation to have greater responsibility in the making of a new society.

The messages that are narrated through Mirriiysaa for their audience concern the general group or individual life of human being and about the governments. In this work, one of my central arguments is that drawing a new and truer picture of the oral narrative tradition can help surmount the social and political deficit.

Then, Mirriiysaa transfers socio-political knowledge from one generation to the other generation. The Hararge Oromo also use Mirriiysaa to tell each other important issue to their day to day life.

Oromo people and socio-political songs are really part of the traditional culture and background of the history and are taught by the Oromo elders to young by using oral literature.

So, in this study, attempts have been made to analyze and point out findings and some major functions of Hararge Oromo Mirriiysaa. Generally, the major role of Mirriiysaa in Hararge Oromo is:

- It plays a role in preserving cultural and socio-political heritage of the society;

- It plays a role in improving social life of the society and encourages how to know their identity;

- It plays a role in addressing political affairs that cannot be expressed directly;

- It plays a role in understanding the past and to shape the present;

- It plays a role in directing the people to live according to their social orders and morality.

\section{Recommendations}

As an attempt is made to present in the analysis part, Mirriiysaa serves various functions in the life of the society. Then, the researcher recommended the following points:-

$\checkmark \quad$ In the society some other studies which are similar with this study should be conducted. For example, faaruu gootaa (songs of heroes), faaruu amantii (religious song), and sirba aadaa (folksong) to depict the socio-political and socio-cultural life of the society.

$\checkmark$ To transmit from generation to generation in formal way cultural songs like songs of heroes should be incorporated in the Educational Curriculum, practically in primary and secondary schools, colleges and higher institutions.

\section{References}

Desta Desalegn. (2015). A Functional Study of Tulama Oromo Oral prose narratives. Addis Ababa University

Dorson, R. (Ed). (1972). Folklore and Folk life: An Introduction. Chicago: The University of Chicago.

Eshete Gemeda. (2008). Oral Narrative Tradition as Field of Scholarship.

Georges, R.A and Jones,M.O (1995). Folkloristics: An Introduction. Bloomington and Indian Polis: Indiana University Press.

Finnegan, R (1970). Oral literature in Africa. Oxford: Oxford University Press.

Hussein, Jeylan Wolyie. "A Critical Review Of The Political And Stereotypical Portrayals Of The Oromo In The Ethiopian Historiography.” Nordic Journal Of African Studies.

Marshal, G. (1992). “Oromo Folktales for a New Generation”. England. 